\title{
Àbèsàbèsì Orthography: A Proposal
}

\author{
Taiwo Opeyemi Agoyi \\ Department of Linguistics and Languages Adekunle Ajasin University Akungba-Akoko Ondo State, Nigeria
}

\begin{abstract}
This paper proposes orthography for Àbèsàbèsì a language known as Akpes in Literature with ethnographic identity ibe. Agoyi 2008 proposed the name Àbèsàbèsì formed from the root morpheme Àbèsì 'we' because it is the only identity accepted by all the nine communities that speak variant of the language. All speakers of the language are aware of the endangered status of the language hence the need to have a writing system that will be used in writing literature in the language for teaching and documenting the language. In line with Nigeria National Policy on Education 2004section 4 subsection 19e states that the medium of instruction in the primary school shall be the language of the environment for the first three years. During this period, English shall be thought as a subject. To be able to implement this policy there is the need to propose orthography for the languages to assist speakers of minority languages who feel the need to safe their languages from death. Since the speakers are familiar with the Yoruba orthography, this paper proposes graphemes that are close to the Yoruba graphemes. The orthography is based mostly on a co-language orthography principle. The proposed graphemes ware tested with literate speakers of the language. In all 37 graphemes are proposed for the consonants, vowels and tone phonemes the various dialects attest.

This research is sponsored by Àbèsàbèsì Language Development committee.
\end{abstract}

Key Words: Àbèsàbèsì multi-dialectal orthography, consonants, vowels, Nasalized vowels, tone, word,

\section{Introduction}

Thames and Hudson (2007:8) say that..... person who can read and write has greater opportunities for fulfillment than one who is illiterate'. Orthography represents wisdom and thought. It puts agreements law, commandments etc on record. It facilitates the growth of a state and people. There is power in the coded word. 'The commandment of a priest or king and his seal could go far beyond his sight and voice and could survive his death. The urgent for immortality has always been the first importance to writers' writing can predict the future. Orthography serves the useful purpose of preserving the language. An endangered language that is reduced to writing for the few interested speakers helps in rekindling speakers' interest in the language. A good orthography helps to preserve the proto- language.

We share Gary Simons (2011)'s view that 'language variation limits communication' He explains that dialectal variation may be so great as to prevent speakers of two dialects of the same language from understanding one another. To him many of the limits to communication can be overcome in written communication. A unified orthography encourages different pronunciations of the same word. Each reader assigns his own pronunciation to the written symbols. In proposing an orthography for Àbèsàbèsì, we take into cognizance Simons' principles of Multidialectal orthography which is always designed to be used by many dialects.

Àbèsàbèsì ( known as Akpes in Literature and identified as ibe in Ethnography) is spoken in nine communities in Akoko division of Ondo State Nigeria. The communities are İyànì, İbaràmù, Gèdègédé, (these three communities are Ìluẹnì) Àsẹ İkáràmù (Èkiròmì), Àkùnnù, Ìlúdọtun, (Akpes) Dája and Ėș ùkù (Ọs ùgù). In proposing Àbèsàbèsì orthography we will adopt the phonemic principle which states that graphemes should be assigned to all significant sounds. Speakers are already familiar with most of the grapheme proposed. Thus the Yoruba orthography as well as availability of graphemes on computer key board serves as a reference point in the choice.

\section{II. Àbèsàbèsì Phonemes}

Àbèsàbèsì attests 22 consonant, seven oral vowels, five nasalized vowels and three level tones phonemes.

\section{Consonants}

The 22 consonants phonemes Àbèsàbèsì attests are presented on a chart thus: Consonant Chart

\begin{tabular}{|c|c|c|c|c|c|c|c|c|}
\hline & Bilabial & $\begin{array}{l}\text { Labiod } \\
\text { ental }\end{array}$ & Alveolar & $\begin{array}{l}\text { Postalve } \\
\text { olar }\end{array}$ & Palatal & Velar & $\begin{array}{l}\text { Labiov } \\
\text { elar }\end{array}$ & Glottal \\
\hline Plosives & $\mathrm{b}$ & & $\mathrm{d}$ & & & $\mathrm{k}$ & $\mathrm{kp} \mathrm{gb}$ & \\
\hline Nasals & & & $\mathrm{n}$ & & $\mathrm{n}$ & y & & \\
\hline Fricatives & $\mathrm{m}$ & $\mathrm{f}$ & $\mathrm{s}$ & $\int$ & & & & $\mathrm{h}$ \\
\hline
\end{tabular}




\begin{tabular}{|l|r|r|r|r|r|r|r|r|}
\hline Affricates & & & & f d & & & & \\
\hline Roll & & & r & & & & & \\
\hline Lateral & & & l & & & & & \\
\hline Approximants & & & & & j & & w & \\
\hline
\end{tabular}

The sounds should be written thus:

Table 1

\begin{tabular}{|c|c|c|}
\hline Phonetic & Phonemic & Orthography \\
\hline $\begin{array}{l}\text { b] } \\
\text { [bae] 'come' [badi] 'beat' }\end{array}$ & $\begin{array}{l}\text { /b/ } \\
\text { /bae/ 'come' /badi/ 'beat' }\end{array}$ & $\begin{array}{l}\text { b } \\
\text { bae 'come' badi 'beat', }\end{array}$ \\
\hline $\begin{array}{l}{\left[\mathrm{b}^{\mathrm{w}}\right]} \\
{\left[\mathrm{e} \mathrm{b}^{\mathrm{w}} \mathrm{i}\right] \text { 'goat' }}\end{array}$ & $\begin{array}{l}/ \mathrm{b}^{\mathrm{w}} / \\
/ \mathrm{e} \mathrm{b}^{\mathrm{w}} \mathrm{i} / \text { 'goat' }\end{array}$ & $\begin{array}{l}\text { bu } \\
\text { ẹbui 'goat' }\end{array}$ \\
\hline $\begin{array}{l}\text { [p] } \\
\text { [ìpว̀mpว̀m] ‘thigh' }\end{array}$ & $\begin{array}{l}\text { /p/ } \\
\text { /ìpว̀mpว̀m/ 'thigh' }\end{array}$ & $\begin{array}{l}\mathrm{p} \\
\text { ìpว̀mpว̀m 'thigh' }\end{array}$ \\
\hline $\begin{array}{l}\text { [d] } \\
\text { [dò]'want' [dàgì] 'vomit' }\end{array}$ & $\begin{array}{l}\text { /d/ } \\
\text { /dò/ 'want' /dàgì/ 'vomit' }\end{array}$ & $\begin{array}{l}\mathrm{d} \\
\text { dò 'want' dàgì 'vomit' }\end{array}$ \\
\hline $\begin{array}{l}\text { [t] } \\
\text { [ta] 'build' [te] 'exist' ' }\end{array}$ & $\begin{array}{l}\text { [t] } \\
\text { [ta] 'build' [te] 'exist' }\end{array}$ & t ta 'build' te 'exist' \\
\hline $\begin{array}{l}\text { [d3] } \\
\text { [dzòmi]'swear'[dze] 'eat' }\end{array}$ & $\begin{array}{l}\text { /dz/ } \\
\text { /dzòmì/ 'swear'/dze/ 'eat' }\end{array}$ & j jòmì 'swear' je 'eat' \\
\hline $\begin{array}{l}\text { [k] } \\
\text { [ko] 'sing' [kàyì] 'count' }\end{array}$ & $\begin{array}{l}\text { /k/ } \\
\text { /ko/ 'sing' /kàyì/ 'count' }\end{array}$ & ko 'sing' kayi 'count' \\
\hline $\begin{array}{l}{\left[\mathrm{k}^{\mathrm{w}}\right]} \\
{\left[\mathrm{ik}^{\mathrm{w}} \mathrm{i}\right] \text { 'penknife' }}\end{array}$ & $\begin{array}{l}/ \mathrm{k}^{\mathrm{w}} / \\
/ \mathrm{ik}^{\mathrm{w}} \mathrm{i} / \text { 'penknife' }\end{array}$ & $\begin{array}{l}\text { ku } \\
\text { ikui 'penknife' }\end{array}$ \\
\hline $\begin{array}{l}\text { [g] 'enough' [gùmù] 'to } \\
\text { [ga] } \\
\text { cover hole' }\end{array}$ & $\begin{array}{l}\text { /g/ } \\
\text { /ga/ 'enough' /gùmù/ 'to cover } \\
\text { hole' }\end{array}$ & $\begin{array}{l}\text { g } \\
\text { ga 'enough' gumu 'to cover } \\
\text { hole' }\end{array}$ \\
\hline $\begin{array}{l}\text { [kp] } \\
{[\text { kpasi] 'hear' [kpani] 'to }} \\
\text { decive/trick' }\end{array}$ & $\begin{array}{l}\text { /kp/ } \\
\text { /kpasi/ 'hear' /kpani/ 'to } \\
\text { decive/trick' }\end{array}$ & $\begin{array}{l}\mathrm{kp} \\
\mathrm{k} \quad \mathrm{kpasi} \text { 'hear' kpani 'to } \\
\text { decive/trick' }\end{array}$ \\
\hline $\begin{array}{l}\text { [gb] } \\
\text { [gbòmi] 'to heat' [gba] 'give' }\end{array}$ & $\begin{array}{l}\text { [gb] } \\
\text { [gbòmi] 'to heat' [gba] 'give' }\end{array}$ & $\begin{array}{l}\text { gb } \\
\text { gbòmì 'to heat' gba 'give' }\end{array}$ \\
\hline $\begin{array}{l}\text { [f] [foi] to uproot' [fü] 'to } \\
\text { cook' }\end{array}$ & [f] [foi] to uproot' [fü] 'to cook' & f foi to uproot' fu 'to cook' \\
\hline [s] sà 'know' sagi 'call' & /s/ /sà/ 'know' /sagi/ 'call' & s sà 'know' sagi 'call' \\
\hline$[$ [ $[$ o] 'weep' [ Jùu 'run' & /J/ $/$ o/ 'weep' / Suu/ 'run' & ș o 'weep' ș uù 'run' \\
\hline $\begin{array}{l}\text { [t] } \\
\text { [tai] 'small' [tfoò] 'lead the } \\
\text { way' }\end{array}$ & $\begin{array}{l}\text { /tt/ } \\
/ \text { tfai/ 'small' /tfoò/ 'lead the way' }\end{array}$ & $\begin{array}{l}\text { tș } \\
\text { tṣ ai 'small' tşoo 'lead the way' } \\
\text { tș ẹyrẹy na 'mend me' }\end{array}$ \\
\hline $\begin{array}{l}{\left[\mathrm{t}^{\mathrm{w}}\right]} \\
{\left[\mathrm{i} \mathrm{f}^{\mathrm{w}} \mathrm{i}\right] \text { 'a type of beans cake' }}\end{array}$ & $\begin{array}{l}/ \mathrm{t}^{\mathrm{w}} / \\
/ \mathrm{i} \mathrm{t}^{\mathrm{w}} \mathrm{i} / \mathrm{\prime} \text { 'a type of beans cake' }\end{array}$ & $\begin{array}{l}\text { tṣ u } \\
\text { ìtș ùì 'a type of beans cake' }\end{array}$ \\
\hline $\begin{array}{l}\text { [h] } \\
\text { [hoi] 'ripe' [honò] 'hard' }\end{array}$ & /h/ & $\begin{array}{l}\text { h } \\
\text { hoi 'ripe' hono 'hard' }\end{array}$ \\
\hline $\begin{array}{l}{\left[\mathrm{h}^{\mathrm{w}}\right]} \\
{\left[\mathrm{ih}^{\mathrm{w}} \mathrm{i}\right] \text { 'urine' }}\end{array}$ & $\begin{array}{l}\text { /hw/ } \\
/ \mathrm{ih}^{\mathrm{w}} \mathrm{i} / \text { 'urine' }\end{array}$ & $\begin{array}{l}\text { hu } \\
\text { ihui 'urine }\end{array}$ \\
\hline $\begin{array}{l}{[\mathrm{m}]} \\
\text { [mi] 'do' [muà] 'full'[imi] } \\
\text { 'pregnancy' }\end{array}$ & $\begin{array}{l}/ \mathrm{m} / \\
/ \mathrm{mi} / \text { 'do' /muà/ 'full'/imi/ } \\
\text { 'pregnancy' }\end{array}$ & $\begin{array}{l}\text { m mi 'do' mua 'full' imi } \\
\text { 'pregnancy' }\end{array}$ \\
\hline $\begin{array}{l}\text { [n] } \\
\text { [nù] 'go' [nani] 'wash } \\
\text { (plates)' [ono] 'a type of seed' }\end{array}$ & $\begin{array}{l}\text { /n/ } \\
\text { /nù/ 'go' /nani/ 'wash (plates)' } \\
\text { /ono/ 'a type of seed' }\end{array}$ & $\begin{array}{l}\text { n nù 'go' nani 'wash (plates)' ono } \\
\text { 'a type of seed' }\end{array}$ \\
\hline $\begin{array}{l}\text { [n ] } \\
\text { [n umi] 'sweat' [on o] 'wife' } \\
\text { [ip i] 'water' }\end{array}$ & $\begin{array}{l}\text { /y / } \\
\text { /y umi/ 'sweat' /on o/ 'wife' /in i/ } \\
\text { 'water' }\end{array}$ & $\begin{array}{l}\text { ny } \\
\text { nyumi ' sweat' onyo 'wife' inyi } \\
\text { 'water' }\end{array}$ \\
\hline $\begin{array}{l}\text { [y] } \\
\text { [ínini] 'four' }\end{array}$ & $\begin{array}{l}{[\mathrm{y}]} \\
\text { /ínini/ 'four' }\end{array}$ & $\begin{array}{l}\mathrm{ng} \\
\text { íningi 'four' }\end{array}$ \\
\hline
\end{tabular}




\begin{tabular}{|c|c|c|}
\hline $\begin{array}{l}\text { [y] } \\
\text { [iyi] 'day' [yo] 'dance' }\end{array}$ & $\begin{array}{l}\text { [y] } \\
\text { [iyi] 'day' [yo] 'dance' }\end{array}$ & $\begin{array}{l}\text { y } \\
\text { iyi 'day' yo 'dance' }\end{array}$ \\
\hline $\begin{array}{l}\text { [w] } \\
\text { [wo] 'resemble' [wosi] 'carry' }\end{array}$ & $\begin{array}{l}\text { /w/ } \\
\text { /wo/ 'resemble' /wosi/ 'carry' }\end{array}$ & $\begin{array}{l}\text { w } \\
\text { wo 'resemble' wosi 'carry' }\end{array}$ \\
\hline $\begin{array}{l}\text { [1] } \\
\text { [lo] 'weave' [logi] 'help' }\end{array}$ & $\begin{array}{l}\text { /1/ } \\
\text { /lo/ 'weave' /logi/ 'help' }\end{array}$ & lo 'weave' logi 'help' \\
\hline $\begin{array}{l}\text { [r] } \\
\text { [erikisi] 'a type of ant' } \\
\text { [okpòro] 'pilar' }\end{array}$ & $\begin{array}{l}\text { /r/ } \\
\text { /erikisi/ 'a type of ant' /okpòro/ } \\
\text { 'pilar' }\end{array}$ & $\begin{array}{l}\mathrm{r} \\
\text { erikisi 'a type of ant' okpòro } \\
\text { 'pilar' }\end{array}$ \\
\hline
\end{tabular}

All the 22 consonants phonemes Àbèsàbèsì attests are represented. Since speakers are familiar with 'ṣ ' used to represent ' '? , I suggest 'tș ' should represent 't $t$.

The choice of 'ts ' is based on the principle of familiarity. The intended user of the orthography are familiar with Yoruba orthography uses 's ' to represent ' $\int$ ' for the voiceless alveolar plosive quality is introduce grapheme to make it sound similar to the phonetic palato- alveolar fricative. The above suggestion is informed by the fact that it is easy for beginner class understand things that look alike. The teacher needs to guide the pupils to take note of the differences in 's' 'ș ' and 'tș ' as graphemes. Furthermore, I propose the nasal quality in ' $\mathrm{n}$ ' and ' $\mathrm{y}$ ' should be represented by writing the grapheme for alveolar nasal ' $\mathrm{n}$ ' to precede ' $\mathrm{y}$ ' and ' $\mathrm{g}$ ' respectively which results in the realization of 'ny' and 'ng,' the grapheme are in agreement with Schroeder 2010:7-8 suggestion for similar phonemes in Bantu Orthography. The above suggestions make the orthography as close as possible to the Yoruba Orthography which learners are already familiar. It also makes the orthography close to languages that attests similar graphemes as Suggested in Schroeder 2010.

\section{Vowels}

(i) Oral Vowels

Oral Vowels: Graphemes for the 7 Àbèsàbèsì oral vowels are shown on table 2 below.

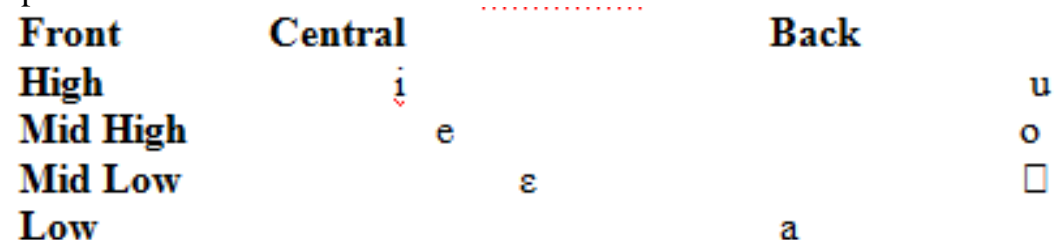

The vowels should be represented as: Table 2

\begin{tabular}{|c|c|c|}
\hline Phonetic Representation & Phonemic Representation & Orthographic Representation \\
\hline $\begin{array}{l}\text { [i] } \\
\text { [imi] 'pregnancy' [iyi] 'day' }\end{array}$ & $\begin{array}{l}\text { /i/ } \\
\text { /imi/ 'pregnancy' iyi/ 'day' }\end{array}$ & imi ‘pregnancy’ iyi ‘day’ \\
\hline [ehu] 'rat' [hu] 'dry' & $\begin{array}{l}\text { /e/ } \\
\text { ehu 'rat' /hu/ 'dry' }\end{array}$ & 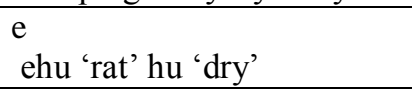 \\
\hline $\begin{array}{l}\text { [o] } \\
\text { [oyo] dance (noun) [ko] 'sing' }\end{array}$ & $\begin{array}{l}\text { /o/ } \\
\text { /oyo/ dance (noun) /ko/ 'sing' }\end{array}$ & $\begin{array}{l}\text { o } \\
\text { oyo dance (noun) ko 'sing' }\end{array}$ \\
\hline $\begin{array}{l}{[\varepsilon]} \\
\text { semé 'greet' }[\varepsilon] \text { 'it' }\end{array}$ & $\begin{array}{l}/ \varepsilon / \\
\text { /sømè / 'greet' /غ́/ 'it' }\end{array}$ & ẹ sẹmẹ 'greet' ẹ́ 'it' \\
\hline [a] [sà] 'know' [bà] 'come' & /a/ /sà/ 'know' /bà/ 'come' & a sa 'know' ba 'come' \\
\hline $\begin{array}{l}\text { [כ] } \\
\text { [obJ] 'hand' [lo] 'throw' }\end{array}$ & $\begin{array}{l}\text { /J/ } / \text { / bo/ 'hand' /lo/ 'throw' }\end{array}$ & $\begin{array}{l}\text { ọ } \\
\text { ọbọ ‘hand' lọ ‘throw' }\end{array}$ \\
\hline$[\mathrm{u}]$ ' fall' [hu] 'die' & $\begin{array}{l}\text { [u] } \\
{[\mathrm{ku}] \text { 'fall' }[\mathrm{hu}] \text { 'die' }}\end{array}$ & u $\mathrm{ku}$ 'fall' hu 'die' \\
\hline
\end{tabular}

Literate speakers, young and old, are familiar with all the graphemes propose on table 2 because of their exposure to Yoruba Literature. Therefore we do not envisage any problem in learning and teaching them.

\section{(ii) Nasalized Vowels}

The five nasalized vowels are:

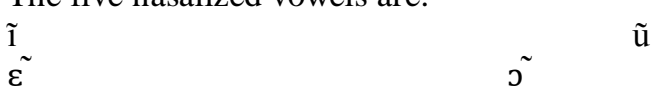

ã

The vowels occur in words as represented on table 3 thus; 
Table 3

\begin{tabular}{|c|c|c|}
\hline Phonetic Representation & Phonemic Representation & Orthographic Representation \\
\hline $\begin{array}{l}\text { [ĩ] } \\
\text { [eki] 'one' [itfi] 'domestic } \\
\text { animals' }\end{array}$ & $\begin{array}{l}\text { /î// } \\
\text { //eki// 'one' /itfi// 'domestic } \\
\text { animals' }\end{array}$ & $\begin{array}{l}\text { in } \\
\text { ekìn 'one' ì tṣ ìn 'domestic } \\
\text { animals' }\end{array}$ \\
\hline 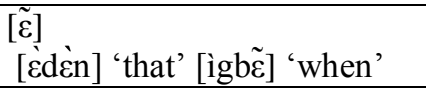 & 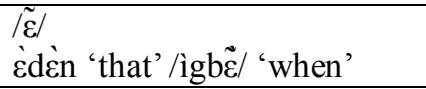 & ện \\
\hline $\begin{array}{l}\text { [ã] } \\
\text { [hãsi] 'peel (yam)' [kpã] }\end{array}$ & $\begin{array}{l}\text { lã/ } \\
\text { /hãsi/ 'peel (yam)' /kpã/ } \\
\text { 'deceive' }\end{array}$ & $\begin{array}{l}\text { an } \\
\text { hansi 'peel (yam)' kpan } \\
\text { 'deceive' }\end{array}$ \\
\hline $\begin{array}{l}{[\tilde{\partial}]} \\
\text { [hว̃] 'cultivate' [hว̃si] 'dry' }\end{array}$ & $\begin{array}{l}\tilde{\partial} / \\
{[\mathrm{h} \tilde{\partial} / \text { 'cultivate' /hõsi/ 'dry' }}\end{array}$ & $\begin{array}{l}\text { ôn } \\
\text { họn 'cultivate' họnsi 'dry' }\end{array}$ \\
\hline $\begin{array}{l}{[\tilde{u}]} \\
{[0 \tilde{u}] \text { 'hill' }}\end{array}$ & 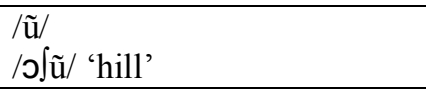 & $\begin{array}{l}\text { un } \\
\text { ọ̣ un 'hill' }\end{array}$ \\
\hline
\end{tabular}

All Àbèsàbèsì vowel phonemes are represented in table 3 .

\section{Long Vowels}

Àbèsàbèsì attests both long and short vowels. Graphemes are already proposed for the short vowels on tables 2 and 3. The long vowels will be represented by double grapheme for the shorter vowels that share similar phonetic features. Examples of such vowels are:

\begin{tabular}{|c|c|c|c|c|c|}
\hline [i:] & /i/ & ii & [uu] & /uu/ & uu \\
\hline [ee] & lee/ & ii & [oo] & /oo/ & oo \\
\hline$\varepsilon \varepsilon$ & $/ \varepsilon \varepsilon /$ & ẹẹ & $\begin{array}{l}{\left[\begin{array}{ll}0 & 0\end{array}\right]} \\
\text { aa }\end{array}$ & / כ כ / & بִִִ \\
\hline
\end{tabular}

The vowels can be found in lexical items like:

ikpẹ dùmẹ ẹ̆y 'guinea warm'

ehii 'word/matter'

èhee ',like this'

èree 'like that'

ikẹ dẹ ẹy̆gbẹ ẹ̆y 'lice'

ínyàádo 'a type of grass hopper'

àjaà 'pot'

ọ̆ọ 'you second person singular'

ayoò 'eye/face'

ítìróò 'eye lace'

Ș uù 'run'

\section{Tone}

Tones are super-segmental phonemes that indicate the pitch of an utterance in a tonal language.

The three level tones Àbèsàbèsì attests should be represented thus:
Low Tone
High Tone
l’] ' ’’̀kàdà
I' $l$ ' 'aye 'mother'
'vagina' èdẹdẹ 'penis' otula 'refuse dung'
Mid Tone
$\Gamma$ / not indicated ẹbui 'goat' ebo 'dog'
oyo 'dance noun'

$$
\text { onyo 'wife' }
$$

\section{Spelling of Words}

Àbèsàbèsì: Words should be spelt as pronounced.

Each (meaningful unit) morpheme should be separated by word spacing. All the three significant tones should be appropriately reflected on the word. Examples are:

ajaà 'pot' àdáà 'hoe' atọ 'land/ground' adomi 'moon' igbadomi 'sky'

ọni 'person' ọbọ 'hand' ș o 'weep 'ș ongi 'turn' iṣ umi 'head' ș erè 'roam about'

etşì 'market' ẹtşa 'evil' ọşişegì 'perforated pot/local sieve' ẹnami 'meat'

ẹ namà 'bird' ẹyggẹy̆ 'door' ẹy̆tẹy̆ngi 'fish' ẹ̌ş̧̧y̆gì 'suffering'

ímonyì 'melon' ọmìnyà 'knife' aṣ ongi mortal ọkurẹy̆ 'cane noun' ọyjọ̣yjọy̆ cake made from water yam' oyẹy̆yẹy̆ ‘a type of beans' òtílí 'type of beans'

ẹkpukpangi 'a type of shrub' ikpado 'groundnut' ikpari 'children' àkpàngì 'chin' ipọymmpọ̆m laps ọmudẹ 'pistol' 
Idaja Igèdègédé Èkiròmì Asẹy̆ İyànì İbaràmù Àkpes

The lexical items above are proposed taking into account the production of the lexis in isolation and in a string morphemic boundary of lexical items in a string will be indicated with word spacing.

For instance an individual from Èkiròmì going to Gègèdédé will say to the neighbour:

$\begin{array}{ll}\mathrm{n} \text { á dasìgèdègédé } & \mathrm{n} \text { á dasi İgèdègédé } \\ \text { I ASP go Igèdègédé } & \text { I am going to İgègèdédé }\end{array}$

ọhunẹ òkúlebàgòrì type of a tree'

tree pre-uproot-dog-bottom

'obeshe'

'òkúlebagori ' is a word form from the combination of four morphemes:

o- kulè- ebo- àgòrì

pre up-root dog -bottom

In the first example two morphemes are contracted in the speech of an Èkiròmì speaker. They are: dasi 'go' and İgèdègédé 'name of a community of Abèsàbèsì speakers'. Thus we propose the separation of each morpheme in structures that attest combination of more than one morpheme.

The universal punctuation principles that govern the use of question mark ?, comma, semi colon; colon : and compound words will be adopted as appropriate in the orthography.

\section{References}

[1] Ahumibe, Chiedozie (2002) Orthography of İlu ẹnì: A proposal. Undergraduate Long Essay, Department of Linguistics and African Languages University of Ibadan, Nigeria.

[2] Arohunmolase L. O., Agoyi T. O etal (2006) The Orthography of IIgau and Iyinno UNESCO: (Lekoba Publishers Ondo).

[3] Arohunmolase L. O., Agoyi T. O etal (2006) A Brief Linguistic Description of IIgau and Iyinno, the Outline of the Social and Historical Situation of the Language and their Communities UNESCO: (Lekoba Publishers Ondo).

[4] Arohunmolase L. O, Agoyi T. O etal (2006) IIgau Alphabetical Word Lists and Vocabulary Items UNESCO: (Lekoba Publishers Ondo).

[5] Arohunmolase L. O., Agoyi T. O etal (2006) Iyinno Alphabetical Word Lists and Vocabulary Items UNESCO: (Lekoba Publishers Ondo).

[6] Arohunmolase L. O., Agoyi T. O etal (2006) IIgau I bi Yonun (1) UNESCO: (Lekoba Publishers Ondo).

[7] Arohunmolase L. O., Agoyi T. O etal (2006) Iyinno Winnigin (1) UNESCO: (Lekoba Publishers Ondo).

[8] Arohunmolase L. O., Agoyi T. O etal (2006) Teaching Mannual: A Handbook Giving Instruction On How To Speak, Read, Teach Learn IIgau and Iyinno UNESCO: (Lekoba Publishers Ondo).

[9] Bamgbose A 1974 Yoruba Orthography UPL Ibadan Friesen Dianne 2001Proposed Segmental Orthography of Mokolo BPP 129Yaoundé Republique Du Cameroun www.google.com search 5/8/2011

[10] Giwa Olabode Biola Not indecated 500 Iyani Dialects with English and Yoruba Translations

[11] Koffi N Ettien Language Planning \& Orthography Design www.google.com search 4/8/2011

[12] Robbinson, Andrew 2007 The Story of Writing Alphabets, Hieroglyphs \& Pictography Thames \& Hudson New York, USA.

[13] Schroeder Leila Bantu Orthography Manual SIL International (2010)

[14] Stark P. Janie 2010 Kambari Orthography SIL International 2010

[15] Simions Gary Principles of Multidialectal Orthography www.google.com search 4/8/2011 